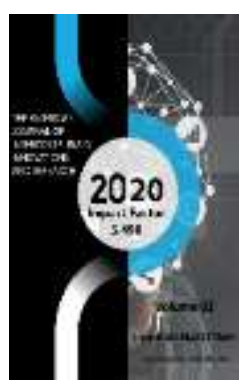

\title{
The Military Army And Its Military Status In The Emirate Of Bukhara In The XVIII-XIX Centuries
}

\author{
Rustam Qarshiev \\ Ph.D., Associate Professor, Uzbekistan
}

Journal Website:

http://usajournalshub.c

om/index,php/tajiir

Copyright: Original content from this work may be used under the terms of the creative commons attributes 4.0 licence.

\section{ABSTRACT}

This article analyzes issues such as the structure of the army in the Emirate of Bukhara in the XVIII-XIX centuries, their combat situation, weapons and methods of their use. The article also provides some information about the changes in the military after the occupation of the Emirate of Bukhara by the Russian Empire, the supply of troops and the combat situation of soldiers, the types of weapons.

\section{KEYWORDS}

Weapons, combat, spear, bow, dagger, daggers, soldiers, supplies.

\section{INTRODUCTION}

If we look at the history of the Uzbek statehood, we see that the military and political power of any country is directly linked to its economic development and potential. However, in the XVIII-XIX centuries, wars between the khanates, internal conflicts in the country deepened the vortex of backwardness. That is why with the first period of the Mangit dynasty's rule, when the emirate became a vassal of the Russian Empire, there were no significant changes in the issue of armaments, the state of the army, its supply. When given information about the weapons of the Emirate of Bukhara, it would be correct to divide them into groups of cold steel and firearms. Among the cold weapons are swords, 
bows, spears, daggers, oybolta, gurzi ... Although the naming of these weapons has changed in terms of quality, we hardly see that they were re-created during the entire Mangit dynasty.

In the sources there are swords called "Chinese", "Russian", "Roman", "Farangi", "Suleiman", "Indian", "Damascus" and others, worn by the soldiers of the Emir $[1 ; 161]$. Sword fighting was rare in medieval Europe and developed countries, but was practiced in the emirate's army until the 1920s. The swords were made by special masters and weighed from $1 \mathrm{~kg}$ to $5 \mathrm{~kg}$. In the Emirate of Bukhara, which became a vassal of the Russian Empire, many weapons called "assoi safari", "assoi jihad" were produced, which served as both sticks and swords, and in the holster of the cane was actually a sword and placed in the abstract.

Weapons in the emirate have been formed over a long period of time and include rifles, pistols and cannons. In the emirate there were lightning rifles, rifle rifles, which were quite obsolete during the Mangit dynasty. Even 2-3 riflemen in each hundred were engaged in morning and evening rifle repair. At a time when the number of fugitive soldiers was increasing, if soldiers escaped with their rifles, the military officers along with them were severely punished. During the vassal period, arms smuggling was on the rise. British $4.3 \mathrm{~cm}$ Peabody-Martini system rifles imported from Afghanistan were bought by Turkmens for 5075 rubles and sold for 75-100 rubles in Karki. It turns out that Habibullah had a secret order to encourage the sale of these rifles, which were brought from Mazar-i-Sharif and Maymana. There are hundreds of letters and messages in the decisions and statements of the Russian government calling for drastic measures to be taken in such cases. However, Russian officials have not been able to eliminate such cases.

In the Emirate of Bukhara, which gained some independence in 1917, a number of measures were taken against the Soviet aggression. It was during this period that many British revolvers of the Smith and Vessona brands were introduced to the emirate. The most influential military men in the Bukhara Emirate were artillerymen, and during the war great confidence was expressed in cannons. Amir Nasrullah is recognized as the Amir who founded the Nizami group of artillerymen from Afghans and infantry in the army. During and after Amir Nasrullah, he was the commanderin-chief of the army. As for the cannons of the Bukhara emirate, the first cannons produced in the emirate were called "Dahanpur" (ie the axis of the cannon is located in the front). The emirate went through the first stage of artillery development - the period of artisanal production - in the process of building dahanpur cannons. The place where the ball was placed was called "Korkhana", and such korkhonas operated in Bukhara, Karmana, Samarkand (until 1868). In the Kokand khanate, these workshops were called "Tubkhona", "Ishkhonai-tobkhona", and balls were produced under the names "Jaloir", "Shohmali", "Yazali".

During the process of transporting the Dahanpur cannons to the battlefield, the cannon cores were transported by a group of "fine soldiers". According to sources, the soldiers were forced to carry 2 to 5 (depending on their weight) cannonballs to the desired area. Powders, which are considered to be the 
most essential for nuclei, have also been produced in the emirate itself since the early 19th century. During the reign of Amir Abdullah Khan, the number of gunpowder producers increased significantly. Another weakness of the Dahanpur cannons 'combat position was that the inside of the cannon barrel consisted of various convex lines, which required the core to also be convex. For bullets, the chances of making such bulges were still low. As a result, these bullets did not fall into the gypsum inside the barrel, and the gunpowder gases formed during the firing came out of the areas that were not glued before the projectile. This would result in the bullet not reaching far, and the barrel would burn and crack.

Dumbalapur cannons were towed with the help of 2 horses and their range was 1-1.2 km. In the middle of the 19th century, Russian army artillery fired at a distance of up to $3 \mathrm{~km}$. Soon, the Banja cannons, made in Russia in 1877 and in France in 1880, had a range of $6 \mathrm{~km}$. During his battles with the Kokand Khanate, Nasrullah captured the cannons of Jahongir and Shokhdor as booty. Seeing the superiority of Jahangir's ball over the Emirate's cannons, Nasrullah declared, "With such a ball, world domination can be established." But the captured Jahangir balls were much heavier and weighed more than 34 pounds ( $544 \mathrm{~kg}$ ). Up to 8 horses could barely pull such a heavy ball. The horned cannons are slightly smaller than the Jahangir and they are set in motion with the help of 6 horses. It is known from the sources that the Iranian and Afghan artillery designers under Amir Nasrullah presented the Amir with projects for the production of steel balls. However, by the end of the entire Mangit dynasty, this had not been done, or rather had not been accomplished, or neglected. The
Europeans had already given up cast iron and bronze balls. Because they were well aware that making the ball out of quality steel would cause the pressure in the barrel to rise, resulting in the projectile going too far.

Although there have been some positive developments in the Bukhara Emirate to modernize armaments and armaments, the emirate has lagged far behind not only Russia and Europe, but also neighboring Afghanistan and Iran, which live in semi-colonial conditions. The task of fully arming the army with firearms has not been solved.

\section{REFERENCES}

1. Sharif Muhammad Mansur Muborakshoh. "Adab al harb wa-sh-shujaat." Dushanbe, 1997.-pp.161.

2. UzR. MDA. I-126- Fund. List 1. Case 1637, 3rd sheet.

3. Own R. MDA, Fund 3.1 List.272 Case. pp 1.

4. Own R. MDA, Fund 3.2 List. Case 171. pp. 187.

5. UzR. MDA. 3rd Fund. List 2. 976-ish. pp 36.

6. Troitskaya A.L. Voennoe delo $v$ Buxare $v$ pervoy polovine XIX veka. -pp. 211

7. Tursunov B. Military work and army in the Kokand khanate: status, management, traditions. (Until the 1970s.) History is a science. nom. diss. ... T., 2006.- pp 134.

8. MDA of the Republic of Uzbekistan. I-126 Fund. List 1. 1636-ish. Sheet 2.

9. Umirzokov Sh. U. History of artillery.-pp 15.

10. Archive of the State Museum of the History of Culture of Uzbekistan in Samarkand. Document № 814, pp 15. 